\title{
Ismo Dunderberg
}

\section{Gnostic Morality Revisited}

[Gnostische Moral neu betrachtet.]

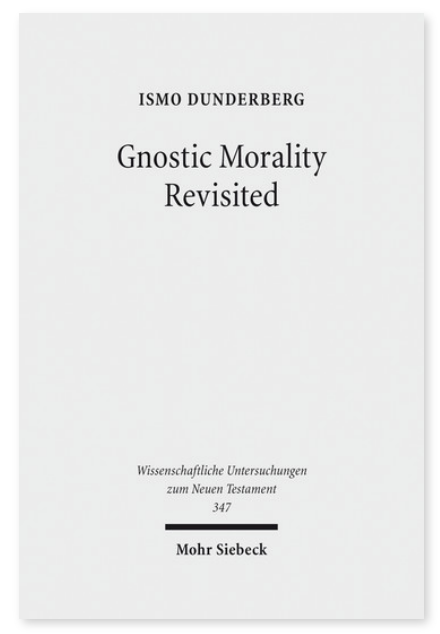

2015. IX, 244 Seiten. WUNT I 347

ISBN 978-3-16-153694-6

DOI 10.1628/978-3-16-153694-6

eBook PDF 129,00€

ISBN 978-3-16-152567-4

Leinen 129,00
Veröffentlicht auf Englisch.

Während einige frühchristliche Texte, die in diesem Band besprochen werden, als "gnostisch« eingeordnet werden, werden sie hier als Zeugen der Ansichten gebildeter Christen angesehen, die im regen Austausch mit philosophischen Traditionen standen. Ismo Dunderberg folgt dem Ansatz, dass die philosophischen Schulen der Antike ihre Anhänger eine Lebensweise lehren sollten und untersucht Fragen zu Moral und Lebensstil in außer-kanonischen Evangelien und in Gruppierungen, die nach und nach in der Kirche als ketzerisch denunziert wurden. Er behandelt die Entwicklung der Seele von materiellen Belangen hin zu einem von Vernunft geleiteten Leben, die Beherrschung der eigenen Emotionen, die Vermeidung von Luxus, den idealen »perfekten Menschen« als ein Werkzeug der moralischen Belehrung, Zuordnungen der Menschen in verschiedene, auf ihrer moralischen Entwicklungsstufe basierende, Gruppen und christliche Debatten bezüglich der Wertigkeit des Märtyrertums. Zudem liefert er eine kritische Bewertung einiger aktueller in der Forschung zum Neuen Testament.

Ismo Dunderberg Born 1963; 1994 Dr. theol. (University of Helsinki); 1995-2003, 2007-08 Research Fellow of the Academy of Finland; 2003-07 Acting Professor of New Testament Studies; since 2008 Professor of New Testament Studies at the Faculty of Theology, University of Helsinki; since 2014 Dean of the Faculty of Theology, University of Helsinki.
Jetzt bestellen:

https://mohrsiebeck.com/buch/gnostic-morality-revisited-9783161536946?no_cache=1

order@mohrsiebeck.com

Telefon: +49 (0)7071-923-17

Telefax: $+49(0) 7071-51104$ 